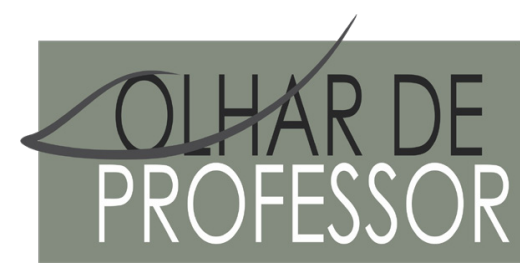

DOI: 10.5212/OLHARPROFR.V.23.2020.16671.209209229053.0817

\title{
O AMOR X O ÓDIO: A ATUALIDADE DO PENSAMENTO DE PAULO FREIRE E O DESASSOSSEGO DOS NEOFASCISTAS NO BRASIL
}

\author{
LOVE X HATE: THE ACTUALITY OF PAULO FREIRE'S THOUGHTS AND THE RESTLESSNESS OF NEOFASCISTS \\ IN BRAZIL
}

\begin{abstract}
AMOR X ODIO: LA ACTUALIDAD DEL PENSAMIENTO DE PAULO FREIRE Y EL DESASOSIEGO DE LOS NEOFASCISTAS EN BRASIL
\end{abstract}

MARIA ELOÁ GEHLEN*

\begin{abstract}
Resumo: Este trabalho reflete a atualidade do pensamento de Paulo Freire e a contraposição ao movimento neofascista no Brasil no século XXI. Por que tanto ódio quando as palavras de Freire conduzem ao amor? O objetivo é clarear os desassossegos que os conceitos, ideias, obras e práticas educacionais de Freire provocam nos seus opositores de extrema-direita. A metodologia consiste em duas histórias de vida com uma professora Freireana e com um cidadão que apoiou o fascismo italiano quando jovem e que, hoje, vive no Brasil. Também foi efetuada uma revisão bibliográfica. Os resultados apontam ao desconhecimento da obra desse educador brasileiro por quem o critica, assim como o descortinar de pessoas que se identificam com ideais fascistas como quem se sente inferiorizado intelectualmente e, assim, cultiva o ódio. Um fator que traz esperança é o surgimento de movimentos antifascistas, responsáveis por manifestações públicas de movimentos sociais populares e do movimento Antifa.
\end{abstract}

Palavras-chave: Paulo Freire; educação libertadora; fascismo; amorosidade.

\begin{abstract}
This article reflects the actuality of Paulo Freire's ideals and its opposition to the neofascism movement in Brazil in this early 21st Century. Why such hate when Freire's words lead to love? This paper aims to clarify the feeling of restlessness that Freire's educational concepts, ideals, pieces, and practices cause in his extreme right-wing opposers. The methodology consists of two life stories with a Freireana teacher and an individual who supported the Italian fascism when he was young and lives in Brazil today. Also, a bibliographic review was held for this article. The results point to the lack of knowledge on Freire's work by those who criticize him, as well as the unveiling of people who identify themselves with fascism ideals as people who feel intellectually inferior and, thus, cultivate hate. A factor that brings hope to the society is the emergence of antifascist movements, the responsible for public manifestations of popular social movements and the Antifa movement.
\end{abstract}

Keywords: Paulo Freire; liberating education; fascism; lovingness.

Resumen: Este trabajo reflete la actualidad del pensamiento de Paulo Freire y su contraposición frente al movimiento fascista en Brasil, en el siglo XXI. ¿Por qué tanto odio cuando las palabras de Freire conducen al amor? El objetivo del artículo es aclarar los desasosiegos que los conceptos, ideas, obras y practicas educacionales de Freire provocan en sus opositores de extrema derecha. La metodología consiste en dos historias de vidas con una profesora freireana y con un ciudadano que apoyó el fascismo italiano en su juventud, y que, hoy, vive en Brasil. Además, se desarrolló una revisión bibliográfica. Los resultados apuntan al desconocimiento acerca del trabajo del educador brasileño por los que lo critican, así como al descortinar de las personas que se identifican con los ideales fascistas como disminuidos intelectualmente y, por tanto, cultivan el odio. Un factor que trae esperanza es

\footnotetext{
* Doutora em Educação (UFRGS), especialista em Educação Inclusiva e Ciências Penais, Graduação em Direito e Pedagogia. Professora adjunta na Universidade Federal da Fronteira Sul - UFFS - Campus Laranjeiras do Sul, PR. E-mail - maria. gehlen@uffs.edu.br
} 
el surgimiento de movimientos antifascistas, responsables por manifestaciones públicas de movimientos sociales populares y del movimiento Antifa.

Palabras-clave: Paulo Freire; educación libertadora; fascismo; amorosidad.

\section{INTRODUÇÃO}

Um assunto atual e relevante é a reflexão sobre as ideias, os conceitos, as obras e a prática de Paulo Freire em contraponto com as informações expostas pelos neofascistas no Brasil.

O desconhecimento da obra e do reconhecimento internacional de Paulo Freire pode levar os incautos a proferir uma série de adjetivos não elogiosos ao Patrono da Educação Nacional. Em algumas passeatas, desde 2018, observei algumas faixas contra Paulo Freire e sua educação libertadora. Também ouvi discursos inflamados de quem não leu sequer uma obra dele, chamando-o de alienador, entre outros impropérios.

Esses fatos geraram uma inquietação em mim, e fiquei a me perguntar: Por que o pensamento, as obras e a ação libertadora de Paulo Freire, no âmbito educacional, geram esse imenso desassossego nos neofascistas do Brasil? Com sua virulência, esse grupo de extrema-direita comprova a atualidade de Paulo Freire, pois, mesmo após mais de 20 anos de seu falecimento, é muito evocado por seus opositores e continua com um grande contingente de admiradores e seguidores freireanos no Brasil e no exterior.

Meu objetivo neste texto é clarear quais são os desassossegos que os conceitos, as ideias, as obras e as práticas de Paulo Freire afloram nos sujeitos da extrema-direita. O corpus da pesquisa consiste em duas histórias de vida: a de uma professora Freireana e a de um cidadão italiano fascista que viveu o período de Mussolini, na Itália, e que hoje vive no Sul do Brasil. Soma-se a isso uma revisão bibliográfica acerca da temática.

O caminho a ser percorrido neste texto consiste, inicialmente, na vida, na obra e nos conceitos inovadores, atuais e relevantes de Paulo Freire. Após, apresento as duas histórias de vida, fruto da pesquisa efetuada. Na sequência, abordo o surgimento do fascismo na Itália, com Benito Mussolini, e seu sucedâneo no Brasil, com o Integralismo de Plínio Salgado e seus seguidores, os camisas verdes. Após, adentro no movimento neofascista que surgiu no Brasil no século XXI, isto é, em suas ideias, suas ações e quais as causas que os levam a criticar Paulo Freire e seu legado no campo educacional.

\section{A VIDA DE PAULO FREIRE}

Um menino nordestino e pobre se tornou uma referência mundial no campo educacional. Paulo Freire fala de si mesmo já desde a minha infância, desde a minha mocidade um pouco atrapalhada, eu era um sujeito que vinha optando, cada vez mais, por um projeto de sociedade que não fosse burguês, que tivesse compromisso com as grandes massas populares espoliadas deste país. (FREIRE apud FIORI, 1991). Mais tarde, Paulo Freire se graduou em Direito, mas escolheu a Educação Popular como mote de sua vida. Tornou-se doutor em Filosofia da Educação e trabalhou como educador no Serviço Social da Indústria (SESI).

Sua vida teve inúmeros desafios. Em 1960, participou da fundação do Movimento de Cultura Popular (MCP), na cidade de Recife, em Pernambuco. Foi membro do Conselho Estadual de Educação, em 1963, nomeado pelo Governador Arraes.

Além disso, no início dessa época, participou do Programa Nacional de Alfabetização no governo do presidente eleito João Goulart. Nessa ocasião, em 1962, aplicou seu método de alfabetização em Angicos, no estado do Rio Grande do Norte, alfabetizando 300 cortadores de cana no tempo recorde de 40 horas. "Quarenta horas de Angicos”, é como foi denominado esse projeto alvissareiro, chamado pelos fazendeiros da região de praga comunista. 
Em razão da ocorrência do golpe militar em 01 de abril de 1964, Paulo Freire ficou preso por mais de 70 dias. Ao ser entrevistado, Paulo Freire revelou (TORRES, 1987, p. 32) "Fui considerado um subversivo intencional, um traidor de Cristo e do povo brasileiro". “... Você nega - perguntava um dos juízes - que seu método é semelhante ao de Stalin, Hitler, Perón e Mussolini? Você nega que com seu pretenso método o que queria era tornar o país bolchevique?”.

Após a prisão, veio o exílio. Freire rumou à Bolívia e depois ao Chile sob a Presidência de Allende, e lá escreveu uma de suas obras mais conhecidas, em 1968: a Pedagogia do Oprimido. Após a deposição de Allende, Freire, em 1969, verificou que era hora de fazer as malas outra vez e foi lecionar na Universidade de Harvard, nos Estados Unidos. De lá, em 1970, partiu para Genebra, na Suíça, onde atuou como consultor educacional no Conselho Mundial das Igrejas.

Na obra Vivendo e aprendendo (1980), ele relata que todo exilado é confrontado com um dilema. A realidade imediata que precisa incorporar, porém sem olvidar sua realidade anterior. Quem perde as raízes perde a identidade.

Porém, seu coração sentia: quanta saudade do Brasil! Sua gente, sua terra. Freire retornou ao Brasil somente em 1980, após a aprovação da Lei de Anistia, e passou a lecionar na Pontifícia Universidade Católica de São Paulo (PUC/SP) e na Universidade Estadual de Campinas (Unicamp). Foi secretário Municipal de Educação em São Paulo, na gestão de Luiza Erundina, e, ao sair, disse:

Sou leal ao sonho. Exigente com a ética. Considero que ela tem a ver com a coerência entre o que se diz e o que se faz. Continuem contando comigo na construção de uma política educacional, de uma escola com outra "cara" mais alegre, fraterna e democrática. Manifesto à maneira de quem, saindo, fica (FREIRE apud FIORI, 1991, p. 144).

Freire é um dos poucos intelectuais brasileiros com reconhecimento nos países ditos desenvolvidos. Ele publicou mais de duas dezenas de livros, os quais foram traduzidos em 35 países. Foi agraciado com 40 títulos de Doutor Honoris Causa, 36 em vida e 4 in memoriam, por Universidades do Canadá, Reino Unido, Itália, Espanha, Portugal, Estados Unidos, Suécia, Alemanha, Argentina e Bolívia. Foi reconhecido seu trabalho com o prêmio da UNESCO de Educação para a Paz, em 1986.

Em pesquisa de 2016, Elliot Green menciona que a obra de Paulo Freire, Pedagogia do Oprimido, é o terceiro livro mais citado na área de humanidades no mundo, com um total de 72.359 citações até o ano da pesquisa de Green.

Paulo tinha proximidade com a Teologia da Libertação da Igreja Católica, com o filósofo Ernani Maria Fiori (com o qual trabalhou no Chile), com o filósofo da educação Álvaro Vieira Pinto, além de Husserl, Sartre, Jasper, Emmanuel Mounier e o italiano Antonio Gramsci.

Freire explicou, em uma entrevista, "isto exige do educador algo que está também nas preocupações de Gramsci - que é o seguinte: jamais se pode separar a sensibilidade dos fatos do rigor dos fatos" (TORRES, 1987, p. 80). Na continuidade da entrevista, Paulo Freire defendeu que "é preciso compreender e respeitar o senso comum das massas populares para buscar e alcançar juntamente com elas uma compreensão mais rigorosa e mais exata da realidade” (TORRES, 1987, p. 82).

A atualidade dos conceitos, método e ideias de Paulo Freire se justificam porque suas obras são referência no meio educacional no Brasil e no mundo. Atualmente, na Alemanha, os ensinamentos de Paulo Freire estão sendo utilizados, assim como o seu método de alfabetização, para dar a conhecer o mundo das letras alemãs aos imigrantes estrangeiros.

Do Nordeste até o Sul do Brasil, Paulo Freire continuava estimulando e dando alento para que todos tivessem condições de ler a vida com criticidade. Suas obras são utilizadas nas Escolas do Campo e nas Escolas Itinerantes do Movimento dos Trabalhadores Rurais Sem Terra (MST), pelo qual Paulo Freire tinha muito apreço. Vargas (2005, p. 177) esclarece que o educador participou, em 25 de maio de 1991, de um dia de debate a respeito da educação popular e da reforma agrária no assentamento Conquista da Fronteira, Hulha Negra, município de Bagé/RS. Na ocasião, Paulo Freire disse:

(...) esta tarde é o começo de algo que já começou. Começou até no momento mesmo das primeiras posições de luta que vocês assumiram, mas esta tarde marca o começo mais sistematizado de um novo processo ou de um desdobramento do primeiro, de um grande processo 
da luta que é um processo político, que é um processo social e que é também um processo pedagógico. Não há briga política que não seja isso. Mas o começo mais sistemático a que me refiro, que hoje se inicia, tem a ver exatamente com dois direitos fundamentais que poucos têm e pelos quais temos que brigar. O direito a conhecer, a conhecer o que já se conhece, e o direito a conhecer o que ainda não se conhece (VARGAS, 2005, p. 177).

A vida de Freire reflete a sua dedicação para que os mais vulneráveis tivessem o direito de conhecer o que se conhece e o que ainda não se conhece. Aquele menino que precisou pegar frutas nos vizinhos para matar a fome, entendeu o funcionamento da sociedade capitalista, dedicando sua vida para trazer a luz do conhecimento para os que dela não podiam se assenhorar.

Além disso, Paulo Freire surgiu com a ideia de fundação do Instituto Paulo Freire (IPF), em 1991, para promover a inclusão social e a redução das desigualdades econômicas, com ações de elaboração de projetos para a Educação, currículos e projetos político-pedagógicos, assim como cursos de formação para alfabetizadores. Essa mente inquieta não parava de funcionar!

Porém, para se ter um melhor conhecimento da trajetória intelectual desse educador, há que se percorrer o caminho dos conceitos e das suas obras, a fim de aquilatar a sua atualidade e relevância na segunda década do século XXI.

\section{OS CONCEITOS INOVADORES, ATUAIS E NECESSÁRIOS DE PAULO FREIRE}

Paulo Freire deixou um grande legado de conceitos, obras e práticas educacionais. Hoje, há um imenso número de seguidores freireanos que demonstram a atualidade de seu pensamento, atualizando-o e oferecendo denúncias, respostas e propostas a políticas educacionais, entre elas, o privilégio da educação das elites, a educação bancária, a reprodução de processos opressivos nas salas de aula, a impossibilidade da educação neutra, a necessidade da conquista da educação crítica, os direitos dos oprimidos ao conhecimento, a esperança e a ousadia que combatem o fatalismo e o medo e a educação na história como possibilidade de mudança (SCOCUGLIA, 2009). Segundo Scocuglia (2009, p. 227), "podemos vislumbrar a Pedagogia social de Paulo Freire como alicerce prático-teórico de uma educação contra-hegemônica combatente da 'cultura educacional mundial comum’”.

Paulo Freire inovou na educação na defesa de conceitos indispensáveis para uma educação libertadora. Para ele, o letramento e a alfabetização estão ligados à vida, devendo ser dada com amorosidade. O educando aprende com as palavras próprias de sua vida, de sua comunidade, de uma maneira amorosa, efetuada pelo educador. Um aluno aprende com um professor afetivo, gentil e dedicado, que o leva facilmente ao mundo das letras para entender e questionar o mundo.

Freire é tão atual, pois conquistou e continua a conquistar educadores porque foi capaz de expressar aquilo que é fundamental na vida de todo ser humano: o amor. Na obra Educação e Mudança (1981, p. 29), Paulo menciona que não há educação sem amor. Quem não é capaz de amar os seres inacabados não pode educar. Não há educação imposta, da mesma forma que não há amor imposto. Não há educação no medo. Nada se pode temer da educação quando se ama.

Esse atual educador alimentou seus escritos e suas aulas com a esperança, que vem do verbo esperançar, não do verbo esperar. A necessidade da educação ser efetuada com estímulos, atiçando o aluno para o conhecimento, estimulando-o para avançar, despertando o seu desejo de saber mais. Uma educação sem esperança de mudanças na vida e na sociedade é uma árvore seca, nada produz. Na obra Educação e Mudança (1981, p. 30), Paulo Freire defende que "uma educação sem esperança não é educação. Quem não tem esperança na educação dos camponeses deverá procurar trabalho em outro lugar”.

Em Que Fazer - Teoria e Prática em Educação Popular (1991), Freire e Nogueira (1991) salientam a satisfação dos profissionais que propõem mudanças e a satisfação do trabalho crítico. São pessoas que semeiam novas direções e contentamento com esse trabalho de qualidade no trato pedagógico. Há solidariedade horizontal nesses gestos coletivos.

Assim, em seus escritos e conferências ele anunciava a necessidade da criticidade, do educando pensar e questionar o porquê das condições de vida e do trabalho dele, de sua família, de sua comunidade, 
de seus pares. Afinal, ele precisa identificar de que lado se encontra na luta de classes. Será sempre um ser subserviente à ordem estabelecida? Como melhorar as suas condições de vida e do coletivo? Sempre foi assim? Ou pode ser diferente?

No posfácio da obra de Fiori (1991), Textos Escolhidos: Educação e Política, Paulo Freire lembrou que, em um seminário em Estocolmo, onde ele disse para os suecos:

Olhem, se vocês quiserem entender o que é luta de classes, melhor do que as referências longínquas de Marx..., se vocês quiserem ver que diabo é isso, vão ao Chile agora, que pegam a luta de classes despida na rua, dando bom dia. As expressões mínimas de confronto de classes estão lá. (FREIRE apud FIORI, 1991, p. 281).

Freire manifestava inconformidade com a educação tradicional, a qual estimula os alunos a decorar conceitos, sem compreendê-los. Para ele, era abominável a educação bancária, à qual o estudante é um mero depositário dos conhecimentos proferidos por um educador, como se ele fosse uma tabula rasa que nenhum conhecimento traz de sua vida e de sua ancestralidade (FREIRE et al., 1980, p. 9-12).

Contudo, de forma simples ele assegurou que é necessário o educador estimular a autonomia no pensamento dos estudantes para que eles não sejam máquinas reprodutoras dos conhecimentos dos mestres. Isso porque é fundamental pensar e questionar, é importante que tenham dúvidas e não apenas certezas. Assim cresce o ser humano, fazendo ciência.

Na obra Vivendo e aprendendo, Freire et al. (1980, p. 11) faz uma crítica ao tipo de escola em vigor nas sociedades altamente industrializadas, pois, a respeito de toda a retórica sobre a igualdade de chances e da educação como fator de emancipação, continua a ser, no fundo, um mecanismo de reprodução das desigualdades sociais.

Uma das obras mais conhecidas de Paulo Freire é a Pedagogia da Autonomia (1996), na qual defende os conhecimentos e práticas necessárias a todo educador. Para ele, há uma necessidade básica de existir relação entre teoria e prática. Não se pode pregar o que não se faz. Ainda, não existe docência sem o educando, pois ensinar tem a ver com a unidade dialética prática-teoria. Prática e teoria se constituem numa unidade contraditória. (TORRES, 1987, p. 104)

Porém, um de seus livros que tem um caráter muito atual, editado em inúmeros países e línguas, é a Pedagogia do Oprimido (1983). O próprio Paulo Freire fala dessa obra: "Quando escrevi esse livro já estava completamente convencido do problema das classes sociais. Inclusive escrevi esse livro com base em minha longa experiência com camponeses no Chile”. (FREIRE apud TORRES, 1987, p. 30).

Em Pedagogia do Oprimido, o conceito de Dialogicidade aparece em relevo, é posto como necessário entre educador e educando. É ele o sustentáculo para a existência do ensino e da aprendizagem. Freire refletia sobre como poderia se dar o diálogo se a pronúncia do mundo é tarefa de homens seletos e se a presença das massas na história é sinal de sua deterioração. Freire defendeu com muita robustez a emancipação dos oprimidos mediante a educação. Para ele, contudo, era necessário se ter ciência da oportunidade que pode transformar o oprimido em opressor e sua contradição. Há indicativos de como superá-la?

A noção Freireana de Dialogicidade se encontra em oposição à manipulação das massas para submetê-las à classe dominante, calando a sua voz como se a voz da elite fosse a única que detém o conhecimento verdadeiro. A ação antidialógica é um modo de colonizar o outro, dominar, conquistar o espaço educacional pela classe dominante.

Em Cartas à Guiné Bissau (1977), Freire explicita a ajuda autêntica como aquela em cuja prática os sujeitos se ajudam mutuamente, crescendo juntos no esforço comum de conhecer a realidade que buscam transformar. É o ato de ajudar que não se distorce em dominação daquele que ajuda sobre quem é ajudado. Por isso é que não há real ajuda entre classes dominantes e classes dominadas, nem entre as sociedades imperiais e as chamadas sociedades dependentes - que são, de fato, dominadas.

Para Freire (TORRES, 1987) a educação tem a qualidade de ser política porque a natureza da prática educativa é política em si mesma. E, por isso, não é possível falar de uma dimensão política da educação, visto que toda ela é política. Essa relação é o que Freire denominou politicidade da educação. 
Além de suas ideias, conceitos e obras, Freire também propusera um método de alfabetização atual, diferente e inovador em relação ao método tradicional. No passado, as pessoas eram alfabetizadas com "Ivo viu a Uva”, pautado na repetição, na memorização de ideias e conceitos alheios ao seu meio ambiente. Paulo Freire ensinou que "o que não se pode fazer é memorizar em vez de aprender. As crianças são obrigadas a repetir. Para mim, só há conhecimento quando se compreende o objeto. Quando você apreende o objeto, necessariamente memoriza o objeto apreendido" (FREIRE apud TORRES, 1987, p. 107).

É uma passagem de um ser humano que conhece a vida e tem ensinamentos, sem ter letramento, para alguém que consegue ter uma leitura do mundo. Ao mesmo tempo em que aprende a ler e escrever, o educando necessita desenvolver o ato de questionar, duvidar, trabalhar para que mudanças sociais profundas aconteçam movidas pela esperança.

Na conversa com Torres (1987), Paulo Freire ponderou que uma questão fundamental para os educadores é saber qual é a nossa compreensão do ato de conhecer: conhecer para quê? Conhecer com quem? Conhecer em favor do quê? Conhecer contra quê? Conhecer em favor de quem? Conhecer contra quem? Em última análise, qual é nossa compreensão político-ideológica de nosso papel como educadores frente aos educandos?

Para esse Freire, não é possível entender a linguagem sem um corte de classe social. Também, uma das qualidades do educador é a coerência entre o discurso e a ação, entre o discurso e a prática. Outra qualidade é a tolerância, enquanto significa a capacidade de conviver com os diferentes para poder lutar contra o antagônico (FREIRE apud TORRES, 1987).

A seguir, apresento duas histórias de vida, com conotações opostas: uma professora freireana e um cidadão italiano, residente no Brasil, com ideias fascistas desde a juventude.

\section{DUAS HISTÓRIAS DE VIDA}

Cabe inicialmente pontuar, o método de pesquisa das histórias de vida. Esclarece Barros (2013) que o movimento de história de vidas nasce das Ciências Sociais e Humanas de tradição filosófica complexa, elaborando criticamente matrizes teóricas alternativas de carácter compreensivo, fenomenológico, interacionista, hermenêutico e existencialista.

A respeito das histórias de vida Pilon e Desmarais refletem (1996, p.11) que depois de 1976, muito mais do que uma ferramenta de recolha de dados, constitui uma forma de abordagem inovadora de um vasto leque de fenômenos etno-psico-sociais (...) dentro da área de investigação. Para Ferraroti (1988) as histórias de vida são um instrumento de investigação e de intervenção, que se baseia numa "hermenêutica da interação" que produz conhecimento através do estabelecimento de uma comunicação interpessoal complexa e recíproca entre o narrador e o narratário que investiga.

Inicialmente, trago a história de vida de uma professora freireana. No Brasil, terra natal de Freire, não são poucas as histórias cruzadas pelas ideias desse educador. Essa professora recebeu-me em sua casa muito disposta e alegre para contar sua história de vida. Ela tem 40 anos, mora sozinha, é solteira. Natural de Porto Alegre (RS) me contou a sua história de vida. Possui formação em Direito e Pedagogia. Ela foi cursar, no início dos anos 2000, uma pós-graduação em Ciências Penais, na Pontifícia Universidade Católica do Rio Grande do Sul (PUC/RS), pois tinha formação em Direito. Uma aula, ao apresentar um seminário em uma disciplina, coube a ela falar da obra de Paulo Freire, Pedagogia da Autonomia. Ao final do trabalho, a docente responsável pelo componente curricular solicitou que ela ficasse no intervalo para conversarem. Toda vermelha, pensando em ter explicado de forma atabalhoada o pensamento desse eminente autor, foi falar com sua mestra.

E qual não foi a sua surpresa, quando a mestra lhe disse que ela estava perdendo tempo nas Ciências Penais, visto que a estudante compreendia e explicava os conceitos de Paulo Freire de maneira muito apropriada, com amorosidade, assim como utilizava a criticidade para interrogar seus colegas. Sua professora lhe disse para ir para o campo da Educação, da Pedagogia, que lá ela poderia realizar um trabalho ao modo de Paulo Freire e seria feliz. E foi o que realmente aconteceu. Hoje, ela leciona no Paraná, na 
Educação do Campo, dialogando com os conceitos, as ideias e as obras de Paulo Freire, com a sensação do dever cumprido em relação aos seus educandos.

Na sequência, apresento a história de vida de um cidadão italiano, residente na região Sul de Porto Alegre (RS), o qual me recebeu em sua residência para dialogar a respeito da sua vida, contente por reviver seu passado. Ele é torcedor do Sport Clube Internacional de Porto Alegre e acolheu-me com um cafezinho e bolachas, gentilmente servidos por sua esposa.

Contou que ele veio ao Brasil por que as condições de vida na Itália estavam difíceis. Ele já era casado com dois filhos homens e não conseguia sustentar sua família na terra natal. Então, decidiu embarcar sozinho para o Brasil e quando tivesse condições econômicas mandaria buscar sua família. Trabalhou aqui, inicialmente, como barbeiro vivendo em um quartinho, juntando dinheiro. Em um ano trouxe sua esposa e os filhos para Porto Alegre (RS). Aqui, depois de certo tempo, ficou viúvo e após alguns anos contraiu novo casamento com uma moça do interior do estado do Rio Grande do Sul, a qual morava em Porto Alegre e trabalhava como auxiliar de enfermagem, em um hospital.

Hoje, bastante lúcido com 91 anos feitos em janeiro de 2020, ele contou a sua vida, na juventude, na Itália. Quando tinha 15 anos e estava na escola de nível médio, perto de sua casa, na Itália, ali veio representante do governo de Benito Mussolini para escolher três ou quatro jovens do sexo masculinos de cada turma, com melhor compleição física e liderança, para participar dos acampamentos e movimentos da juventude fascista. E ele foi um desses escolhidos. Ele participou de inúmeros acampamentos de jovens que idolatravam Benito Mussolini. Eles faziam muita ginástica, desfiles cívicos, aprendiam o hino do partido nacional fascista. Nesses espaços, era forte a reverência ao grande líder Mussolini, às ideias nacionalistas e à visão de extrema-direita.

Esse cidadão italiano me contou fatos da história de sua vida, pois na Segunda Guerra Mundial, ele e seus companheiros da juventude fascista passaram a levar baldes de água para matar a sede dos soldados alemães, que se encontravam escondidos nas cavernas, nas proximidades de onde moravam. Em troca, eles recebiam salsichas em conserva e outras comidas enlatadas, como recompensa pela ajuda aos soldados nazistas.

Até hoje, na casa onde ele mora na zona sul de Porto Alegre, quando recebe a visita de um amigo italiano daqueles tempos do fascismo, eles se cumprimentam cantando o hino do partido nacional fascista de Benito Mussolini. Ele casou jovem na Itália, trouxe a família para o Brasil, em virtude das dificuldades financeiras para sobreviver no seu país natal. Criaram seus dois filhos homens trabalhando, inicialmente como barbeiro e depois no comércio e, ainda hoje, revela sua aderência a partidos de extrema-direita no Brasil. Ele continua fiel aos ensinamentos de Mussolini, inculcados na sua mente na juventude fascista.

Assim, após a exposição de duas histórias de vida, a última de um cidadão italiano com pensamentos fascistas morando no sul do Brasil, cabe encaminharmos para desvelar o pensamento fascista de Benito Mussolini e seus seguidores, na Itália, para conhecer essa forma totalitária de ação e pensamento desde o seu nascedouro, em 1922, para depois, poder compreender por que Paulo Freire gera desassossego em um grupo neofascista no Brasil, após mais de vinte anos de sua morte.

\section{O ASCENDER DO FASCISMO NA ITÁLIA COM BENITO MUSSOLINI}

O Fascismo foi um movimento político, gerado após a Primeira Guerra Mundial (1914-1918), a partir de uma grave crise econômica na Itália, formado por milícias organizadas por Benito Mussolini naquele país. Esses grupos armados eram organizações paramilitares que usavam enorme violência para impor seus ideais. Eram reconhecidos pelo uso de camisas negras, e, armados, dirigiam sua ação militar contra associações de operários, sindicalistas e quem mais se opusesse aos seus desideratos.

Em 1922, Mussolini conduz a Marcha sobre Roma, culminando na sua tomada do poder e, a partir disso, instala um regime ditatorial, totalitário e ultranacionalista. Dessa forma governou a Itália até sua morte. O símbolo dos fascistas era um feixe amarrado junto a um machado, o qual significava a união dos diferentes por um mesmo propósito. 
Eles também difundiram, largamente, o Hino Oficial do Partido Nacional Fascista, denominado Giovinezza (Juventude), escrito por Giuseppe Blanc, em 1909, no qual os versos exprimiam:

\author{
Poetas e artesãos \\ Os senhores e os camponeses \\ Com orgulho italiano Mussolini jura fé. \\ Não há bairro pobre \\ Que ele não envia suas fileiras \\ Que você não explica as bandeiras \\ Redentor fascismo. ” (BLANC, 1909).
}

Os fascistas liderados por Mussolini tiveram vasta atividade no meio educacional. Umberto Eco (2018), em uma conferência na Columbia University em 1995, revelou que sua infância foi marcada pelos grandes e históricos discursos de Mussolini, cujos trechos significativos aprendiam de cor na escola. Eco ganhou o primeiro prêmio nos Ludi Juveniles ao dissertar a respeito do tema "Devemos morrer pela glória de Mussolini e pelo destino imortal da Itália?”. Para esse autor, o fascismo de Mussolini tinha como base a ideia de um chefe carismático, o corporativismo, a vontade imperialista de conquistar novas terras, um nacionalismo exacerbado, com uma nação inteira vestida com as camisas negras, a recusa à democracia parlamentar e o antissemitismo.

Para o autor acima citado, Mussolini não tinha qualquer filosofia: tinha apenas retórica. O fascismo italiano foi à primeira ditadura de direita que dominou um país europeu. Todos os movimentos análogos encontraram uma espécie de arquétipo comum no regime de Mussolini.

Antonio Gramsci, um intelectual italiano de envergadura, foi preso pelo regime de Mussolini e condenado à prisão, mesmo sendo deputado e tendo imunidade parlamentar. Era preciso calar as vozes e os pensamentos contrários ao regime fascista.

O fascismo italiano, para Umberto Eco (2018), possuía as seguintes características: 1) o culto à tradição; 2) a recusa à modernidade; 3) a ação pela ação (irracionalismo); 4) o desacordo é traição, isto é, não aceita críticas; 5) ele provém da frustração individual ou social (apelo às classes médias frustradas); 6) nacionalismo exacerbado, obsessão pela conspiração internacional; 7) seus membros devem se sentir humilhados pela riqueza ostensiva e pela força do inimigo; 8) é racista por definição; 9) o pacifismo é mau porque a vida é uma guerra permanente; 10) os membros do partido são os melhores cidadãos do mundo, organizados de forma hierárquica ao estilo militar; 11) cada um é educado para ser um herói, o culto ao heroísmo é ligado ao culto à morte; 12) Transferência da sua vontade de poder para questões sexuais, como o machismo, e intolerantes à homossexualidade e à castidade; 13) O povo é uma ficção teatral que exprime sua vontade mediante a palavra de seu líder.

Para Konder (2009), o fascismo é um movimento político de conteúdo social conservador, que se disfarça sob uma máscara modernizadora, e é manipulador, antidemocrático, antissocialista, antioperário, com influência junto às massas em uma sociedade marcada pela presença do capital financeiro e massas de consumo dirigido.

Com um olhar voltado para as subjetividades, Wilhelm Reich (1978) trata da psicologia de massas do fascismo e vai além, pois descortina que, para se ter o domínio das massas era imprescindível a noção de honra pessoal, honra da família, honra da raça e honra nacional em uma sociedade patriarcal, com repressão sexual, luta pessoal contra a própria sexualidade e a instituição do matrimônio compulsivo.

Para Reich (1978), na Itália, a classe média começou a se movimentar e apareceu como força social sob a forma do fascismo. A classe média tem uma força social extraordinária, que em muito ultrapassa a sua posição econômica. É a camada que retém e conserva, com todas as suas contradições, vários milênios de regime patriarcal. A conclusão de Reich (1978) é que o fascismo apenas liberaria os impulsos adormecidos dentro de cada um de nós. O fascismo seria a organização dos nossos instintos: somente a liberação controlada da sexualidade e da combatividade evitaria que elas se desrecalcassem na agressividade fascista. As causas econômicas do fascismo se juntariam às contradições da vida sexual e à repressão da vida amorosa dos homens.

Paris (1976) conclui em sua obra As origens do Fascismo, que a falsa consciência e o próprio fascismo se mostram sujeitos à mesma análise que a esquizofrenia. Uma simples analogia? Ou trata-se 
efetivamente de uma homologia? A história do fascismo é um grande livro no qual a psiquiatria também encontra um discurso que lhe é familiar. As estruturas homólogas sugerem ancestralidade comum. Paris cita (1976) Turati para dizer que o fascismo é "um produto cujos germes fermentam em todos os Estados capitalistas” (TURATI apud PARIS, 1976, p. 106).

O fim do ditador fascista Mussolini aconteceu no fim da Segunda Guerra Mundial. Ele foi fuzilado em praça pública por membros da resistência italiana (denominados partigiani). Em Milão, seu corpo ficou exposto, pendurado de cabeça para baixo, em uma viga de metal.

Triste fim a um ditador fascista que serviu de modelo a um movimento fascista brasileiro: o Integralismo.

\section{O FASCISMO NO BRASIL E O INTEGRALISMO}

Um movimento semelhante ao fascismo italiano de Benito Mussolini constituiu-se, no Brasil, a partir de 1932, na chamada Ação Integralista Brasileira (AIB), mediante a direção de Plínio Salgado, seu maior ideólogo. Seus adeptos eram jovens de até 30 anos, pequenos agricultores e fazendeiros. Eles usavam camisas verdes com o emblema do Sigma. Era um grupo de extrema-direita, cujo lema era "Deus, pátria e família”. Tinham ideias anticomunistas e contra os socialistas e o capitalismo internacional financeiro.

Hélgio Trindade, um autor clássico no assunto, expõe que a AIB foi um movimento de inspiração fascista com organização de massa, cuja força política era estimada entre 600 mil e um milhão de adeptos. Os valores que defendiam eram o nacionalismo, o amor à pátria e à disciplina, a subordinação à chefia e à hierarquia, o juramento de obediência, a lealdade e a exaltação da virilidade. Eles realizavam exercícios físicos, desfiles com bandeiras e exaltavam valores cívicos. Essa organização nasceu numa fase de ascensão das ideias autoritárias de extrema-direita, a partir do marco político estabelecido pela Revolução de 1930. Plínio Salgado, então deputado, viajou à Europa, onde se fascinou com a experiência fascista (e inclusive entrevistou Mussolini), conscientizando-se da fragilidade da democracia liberal. A tendência majoritária da AIB de inspiração fascista encontrava-se em torno de Plínio Salgado, com um grupo de estudantes da Faculdade de Direito de São Paulo, do qual fazia parte Alfredo Buzaid, entre outros (TRINDADE, s.d.)

Bertonha (2011) conclui que o integralismo pode ser classificado, conceitualmente, como um tipo de fascismo, próximo ao italiano. O regime de Mussolini era visto com muita simpatia pelos membros do integralismo. Muitos descendentes de italianos estavam em suas fileiras, a ponto de Roma enviar subsídios financeiros aos integralistas.

No tocante a esse movimento integralista, Trindade (2016), expõe o pensamento de Stanley Payne, da University of Wisconsin, para quem o único grupo que alcançou real importância e que, de fato, se converteu no único grande partido latino-americano que se aproximou em quase todos os aspectos do fascismo europeu foi a AIB de Plínio Salgado, fundada em 1932.

Nesse movimento de extrema-direita, a Igreja Católica era representada por Alceu Amoroso Lima, que dirigia o Centro Dom Vital como o principal líder do catolicismo brasileiro, no enfrentamento a Anísio Teixeira, Lourenço Filho, Fernando Azevedo e aqueles que assinaram o Manifesto dos Pioneiros pela Educação Nova, em que defendiam a separação do Estado da Igreja visando a uma educação laica.

Na obra O fascismo brasileiro na década de 30, Trindade (1974) afirma haver uma mística nessa organização, com rituais e doutrinação. Utilizavam casamentos, batismos e cerimônias fúnebres para reverberar suas ideias e propósitos, com ritual de iniciação no movimento, com juramento de fidelidade.

Um fato marcante ocorreu no dia 07 de outubro de 1934. Conhecido como a revoada das galinhas verdes, foi um enfrentamento entre integralistas e comunistas na Praça da Sé, em São Paulo. Conforme levantamento de Ramos (2016, p. 12),

O Jornal já em sua primeira página estampa uma foto do ocorrido e dá seu veredicto: “ataque do Partido Comunista à comemoração integralista”. Tomado o depoimento do chefe de polícia Christiano Altenfelder, o mesmo informa que a polícia tentou evitar o conflito, mas que devido 
ao fato dos comunistas estarem escondidos em prédios residenciais, praticamente inviabilizou o trabalho ostensivo (O Jornal, 09/10/1934).

Scarzanella (2005, p. VIII), na obra Fascisti in Sud America, explicita que "há, no Brasil, os italianos da segunda geração incauta, senão breve, abertura de confiança em relação a um promissor partido ‘irmão’, a Ação Integralista Brasileira de Plínio Salgado”.

Mas, com a instalação do Estado Novo, um decreto extinguiu todos os partidos políticos, inclusive a Ação Integralista Brasileira. Como reação, os integralistas tentaram um assalto ao poder em 10 de maio de 1938, atacando o Palácio Guanabara, que abrigava Getúlio Vargas. Porém, foram derrotados e presos (VARGAS, 1995, p. 130-131).

O Estado Novo foi um projeto de Estado fascista ao estilo brasileiro, delineado por Getúlio Vargas, em 1937, ancorado em um forte Departamento de Imprensa e Propaganda (DIP), o qual cerceava os meios de comunicação na busca de consenso na sociedade. Havia a exaltação dos grandes heróis da pátria, a mística do regime e sua eternidade futura, a defesa da importância da raça, da juventude e a valorização da figura do chefe.

A educação escolar também foi utilizada como aparelho ideológico do Estado Novo. "O campo educacional foi um dos alvos eleitos. Era um espaço com poder de moldar a sociedade a partir da formação das mentes (...) e a educação seria a arena principal em que o combate ideológico se daria” (SCHWARTZMAN; BOMENY; COSTA, 1984, p. 51).

Com a instalação do Estado Novo e a ditadura Vargas, em 1937 a AIB se desfez, porém, hoje, ainda há netos dos integralistas, que difundem o seu ideário mediante redes sociais, verificando-se a continuidade desse grupo e suas ideias de extrema-direita, no Brasil.

\section{O NEOFASCISMO NO BRASIL NO SÉCULO XXI}

Marcado pelas manifestações de junho de 2013, que reivindicavam o passe livre nas passagens de ônibus em São Paulo, tem-se o nascedouro de um movimento movido por estudantes e trabalhadores. Esse episódio foi apropriado pela direita no Brasil, que utilizou essa organização de massas para espraiar as ideias que viriam a culminar no golpe contra a presidenta eleita, Dilma Roussef, em 2016. Na ocasião das manifestações se juntaram o Movimento Brasil Livre (MBL), o movimento Vem Pra Rua, setores financistas e outras organizações sociais menores para impulsionar a derrocada da democracia e a ascensão das ideias conservadoras, com a finalidade de implantar o ultraliberalismo no país.

No Brasil, no século XXI, aparecem os movimentos neofascistas amparados em figuras instalados no aparelho estatal, utilizando-se das redes sociais (Whatsapp, Facebook, Instagram e outras) para disseminar suas ideias e propósitos. Com um linguajar primitivo, não admitem o contraditório, julgando-se senhores do "novo" Estado brasileiro. Demonstram cultuar a figura do chefe, a obediência à hierarquia e à disciplina, o gosto pelo poder com atitudes agressivas, porém, trazem a contradição de não serem nacionalistas por reverenciarem os Estados Unidos.

Eles contradizem os ensinamentos de Paulo Freire, a quem se referem como fonte de alienação, a quem odeiam sem ao menos conhecer suas obras. Atitude condizente com quem se situa inferiorizado intelectualmente, ressentidos talvez, recalcados sexualmente, com o incômodo de não terem, no seu campo de extrema-direita, referências brilhantes, reconhecidas em âmbito mundial. Seu grande referencial teórico é o astrólogo Olavo de Carvalho, que reside na Virgínia, nos Estados Unidos. É a revelação da carência intelectual dos neofascistas em não conseguir compreender a magnitude da vida e obra de Paulo Freire e seu imenso legado no campo educacional.

Os neofascistas, com uma postura arrogante, querem intimidar pobres, negros, pessoas da comunidade LGBTQ+, indígenas, moradores de rua, sem-terra e mulheres com atitudes e expressões machistas e um servilismo abominável aos Estados Unidos da América. Portanto, essa mostra de Estado fascista, no Brasil, não possui a característica do fascismo italiano de ser nacionalista.

As ideias-chave desses movimentos de extrema-direita, no Brasil atual, situam-se em discursos de ódio contra Paulo Freire, assim como manifestações de xenofobia, contra o aborto e em defesa inflamada 
da pátria, da família e de Deus acima de tudo. Ainda, defendem a meritocracia na educação, o casamento somente entre heterossexuais, os valores ditos cristãos, as pessoas "de bem" (sem explicitar a que bem se referem).

Repetindo slogans e chavões como "Deus, Pátria e Família”, atuam nas redes sociais atacando os comunistas, os gays, as feministas. Os neofascistas propagam uma lição aprendida e decorada, construída por suas lideranças, sem nenhuma acepção crítica, não tendo conhecimento teórico do que entendem por comunismo, feminismo, nem quais as ideias, conceitos e obras de Paulo Freire atacam.

Note-se essa característica única desse fascismo brasileiro, que grita pela pátria, mas não é nacionalista e presta continência à bandeira de outro país (Estados Unidos). É um modelo de Estado fascista com características próprias, destoando do modelo de fascismo italiano, de Benito Mussolini.

Contudo, a contradição está afirmada e a esperança ressurge, em 2020, com a organização de movimentos antifascistas que congregam torcidas organizadas de times como o Corinthians, o Palmeiras, o Internacional, bem como Movimentos Sociais Populares, entregadores de aplicativos de comida, o Movimento de Policiais Antifas, o Movimento dos Trabalhadores Sem-Teto e partidos políticos de esquerda.

Esses grupos trazem à lembrança o jogador Sócrates, que fundou a Democracia Corintiana, junto com Casagrande e outros jogadores, no enfrentamento à Ditadura Militar-Empresarial de 1964-1985. Quando Sócrates foi jogar na Itália, no Fiorentina, “um jornalista perguntou ao Sócrates: Quem é o italiano que mais estima Mazzola ou Rivera? Sócrates respondeu: Não os conheço. Estou aqui para ler Gramsci na língua original e estudar a história do movimento operário”.

\section{POR QUUE OS NEOFASCISTAS TÊM DESASSOSSEGO COM PAULO FREIRE?}

E as pessoas que passarem Querida, adeus! Querida, adeus! Querida, adeus, adeus!

E as pessoas que passarem Me dirão: Que bela flor! E essa será a flor da Resistência Querida, adeus! Querida, adeus! Querida, adeus, adeus! E essa será a flor da Resistência Daquele que morreu pela liberdade

Hino da Resistência italiana ao Fascismo, letra traduzida da canção Bella Ciao

Com o hino da resistência italiana ao fascismo, com o símbolo da flor da resistência, passo a dissertar sobre o porquê de os fascistas brasileiros terem desassossego com a vida e obra de Paulo Freire.

No Brasil pós-golpe de 2016, em algumas passeatas surgiram faixas contrárias a Paulo Freire, suas ideias, conceitos e obras, além do seu modo de educar. Quais as razões que levam algumas pessoas de pensamento e ações fascistas a exporem publicamente sua contrariedade àquele que é o Patrono da Educação Brasileira, declarado pela Lei n. ${ }^{\circ}$ 12.612/2012 (BRASIL, 2012), e reconhecido mundialmente por seus ensinamentos?Mesmo sem conhecer suas obras, eles percebem em Paulo Freire, um símbolo de resistência a esse Estado fascista instaurado no Brasil, como a bela flor da Itália, que teima em se afirmar viva, mesmo em um terreno ideológico árido, onde não se admite o contrário, nem a liberdade de pensamento do outro.

Inicialmente, há de se convir que essas massas neofascistas não conhecem e nem discutem o pensamento, as obras e o método de Paulo Freire. Eles apenas repetem os chavões e slogans de seus ideólogos, entre eles o astrólogo Olavo de Carvalho. Porém, há que se verificarem as contradições e os contrapontos que o pensamento de Paulo Freire faz emergir do pensamento neofascista. Paulo Freire insistia no conceito de amorosidade do educador, no trato com as pessoas, com seus educandos, no valor inestimável do amor. Ao contrário, os neofascistas pregam o ódio às populações vulneráveis econômica e socialmente, como negros, pobres, pessoas LGBTQ+, indígenas, mulheres, moradores de rua e imigrantes. 
Ao expor o conceito de criticidade, Freire entende a necessidade de as pessoas pensarem por si próprias e tirarem conclusões de como se encontra o sistema econômico, a sua situação de vida, o emprego, a moradia, a saúde e a educação para todos. De modo contrário, os manifestantes neofascistas possuem características de alienação ao repetir os bordões e slogans que as lideranças expõem nas mídias. Eles não conhecem e não querem conhecer um pensamento diferente do seu. Ficam embotados em simplificações e comentários repetitivos das redes sociais, das mídias interativas.

Freire, com suas ideias e obras fecundas, representa uma resistência ativa ao sistema capitalista com o anúncio da possibilidade de um sistema coletivo, com o repartir das riquezas entre todos, com acesso aos bens de produção e consumo às populações vulneráveis, com igualdade nas condições de vida, superando, assim, um sistema de exploração da grande massa de trabalhadores. Por outro lado, os novos fascistas defendem a individualidade de forma acirrada, o acúmulo de bens para poucos, a meritocracia, a continuidade das desigualdades sociais e econômicas, baseados no nascimento ou no merecimento de poucos.

Quando uma pessoa conquista a autonomia, torna-se livre, não fica mais refém da opinião dos outros. Ela possui sabedoria e discernimento para compreender qual é o mundo que ela deseja para si e para as próximas gerações, com respeito às outras pessoas, ao meio ambiente e ao planeta. Esse é o pensamento de Paulo Freire. O contrário das ideias de autonomia de Freire advém dos conceitos de dependência, servidão, submissão da maioria da população ao pensamento de uma elite minoritária. É domesticar e direcionar uma parcela da população neofascista, que segue as orientações de seus líderes sem questioná-las. Eles são favoráveis ao desmatamento da Amazônia por meio da invasão das Terras Indígenas por grileiros, pois o que importa é o lucro, acima de tudo.

Paulo Freire se opunha à educação tradicional, baseada no aluno como tabula rasa na qual o educador iria depositar seus conhecimentos. Defendia que todos têm conhecimentos adquiridos em conjunto com seus pares, seus vizinhos, no entorno onde vivem. Para Freire não há necessidade de se decorar conceitos, mas, sim, de entendê-los e verificar como aplicá-los na vida. As ideias contrárias a Freire, expostas pelos neofascistas, baseiam-se na meritocracia, no acúmulo de conhecimentos pelos estudantes, no professor como o senhor de todo o conhecimento e no aluno como um receptor passivo, sem condições de contribuir ao conhecimento.

Por fim, uma das ideias-chave de Paulo Freire é a esperança, do verbo esperançar, que indica possibilidades de mudanças no sistema vigente, assim como nas condições de vida, saúde e educação de toda a população. Isso é o que atormenta seus adversários, pois eles querem se impor mediante o medo, o despertar do pânico e o desespero das populações fragilizadas ante o desalento de sua situação econômica e social. Os neofascistas querem indicar que não há mais solução, o caminho é a submissão aos seus desideratos Freire, por sua vez, traz o anúncio de que outro mundo é possível.

\section{CONSIDERAÇÕES FINAIS}

Este trabalho demandou o esforço de, em poucas páginas, dar o conhecer à obra imensa, atual e relevante do educador Paulo Freire. Parti da angústia inspiradora, que me solicitava respostas. Por que tanto ódio dos neofascistas, no Brasil, se as palavras de Freire conduzem ao amor ao próximo, aos educandos? Por que faixas negam, em passeatas, o legado do Patrono da Educação Brasileira?

Visando a clarear os desassossegos que os conceitos, ideias, obras e práticas educacionais de Paulo Freire provocam nos neofascistas de extrema-direita, estabeleci esse como o objetivo que encaminhou o trabalho.

Procurei demonstrar a relação da história de vida de uma professora com o legado de Paulo Freire e outra história de vida de um jovem fascista italiano e que, hoje, é um ancião que mora no Sul do Brasil, onde continua com as ideias e anseios de Benito Mussolini. Além disso, foi efetivada uma revisão bibliográfica. 
Já se passaram mais de duas décadas da morte de Paulo Freire. Isso indica que esse grupo neofascista de extrema-direita comprova a atualidade de Paulo Freire, pois ele é muito evocado por seus difamadores e continua com um grande contingente de admiradores e seguidores no Brasil e no exterior.

O caminho percorrido consistiu na vida, obra e nos conceitos inovadores, atuais e relevantes de Paulo Freire. Na sequência, dissertei sobre o surgimento do fascismo na Itália, com Benito Mussolini, e seu sucedâneo no Brasil, com o Integralismo de Plínio Salgado e seus grupos das camisas verdes. Com a instalação do Estado Novo, com Getúlio Vargas, em 1937, foi estabelecido um novo Estado fascista e houve o desaparecimento do integralismo.

Após, apresentei o movimento neofascista que surgiu no Brasil, no século XXI, com a exposição de suas ideias, ações agressivas e disseminação do ódio, bem como o seu desconhecimento do legado de Paulo Freire, de seus livros, ideias e práticas. Como odiar o que não conhecemos? Talvez esse seja um sentimento de quem se sente inferiorizado no campo educacional, recalcado no setor sexual, ressentido pelo brilho e projeção internacional de Paulo Freire, o que muito o contraria e lhe provoca desassossego. Talvez a contrariedade dos neofascistas venha de não terem no seu campo de extrema-direita, referências reconhecidas em âmbito mundial. Pode ser uma revelação de carência intelectual em conseguir compreender a magnitude da vida e obra de Paulo Freire e o seu imenso legado no campo educacional.

$\mathrm{O}$ que nos traz a esperança é o surgimento de movimentos antifascistas nas torcidas de grandes clubes como o Corinthians, Internacional, Palmeiras, assim como um movimento com mais de 500 integrantes na Polícia Civil do país, com o apoio de movimentos sociais populares, grupo de entregadores de aplicativos de comida, entre outros.

Paulo Freire é luz para quem trabalha no campo educacional. Após mais de duas décadas de sua morte, surgiram às trevas do neofascismo. E, agora, novamente o resplendor das ideias e conceitos freireanos aparecem nos movimentos antifascistas que saíram às ruas contra o Estado fascista.

A história apresenta o resgate da obra atual e relevante de Paulo Freire. Para seus opositores, o esquecimento na história será sua grande lição.

\section{REFERÊNCIAS}

BARROS, R. O Movimento das Histórias de Vida e a Educação de Adultos de Matriz Crítica: ideias e conceitos em contexto. Rev. Lusófona de Educação n. o 23, Lisboa, 2013

BELLA CIAO (Querida Adeus). Autor Desconhecido. Hino da Resistência italiana ao Fascismo. Disponível em: https://www.letras.mus.br/banda-bassotti/1080528/traducao.html. Acesso em 28 de jul. de 2020.

BERTONHA, J. F. Plínio Salgado, o integralismo brasileiro e as suas relações com Portugal (19321975). Análise Social, v. XLVI, n. 198, p. 65-87, 2011.

BLANC, G. Giovinezza (Juventude), 1909. Disponível em: www.musixmatch.com. Acesso em 30 de mai. De 2020.

BRASIL. Lei n. ${ }^{\circ}$ 12.612/2012. Declara o educador Paulo Freire Patrono da Educação Brasileira. Brasília, 2012. Disponível em: http://www.planalto.gov.br/ccivil_03/_Ato2011-2014/2012/Lei/L12612. htm. Acesso em 23 de jul. de 2020.

ECO, U. O Fascismo eterno. Tradução de Eliana Aguiar. 1. ed. Rio de Janeiro: Record, 2018.

FERRAROTI, F. Sobre a Autonomia do Método Biográfico. In AAVV. O Método (Auto) biográfico e a Formação Lisboa: Ministério da Saúde. 1988. p. 15-35.

FIORI, E. M. Textos escolhidos: Educação e Política. v. II. Porto Alegre: L\&PM, 1991.

FREIRE, P. Pedagogia da autonomia: saberes Necessários à prática acadêmica. 25ª Ed. São Paulo: Paz e Terra, 1996.

FREIRE, P. Pedagogia do Oprimido. São Paulo: Paz e Terra, 1983. 
FREIRE, P. Educação e Mudança. Tradução de Moacir Gadotti e Lilian Lopes Martin. Rio de Janeiro: Paz e Terra, 1981.

FREIRE, P. Cartas à Guiné-Bissau: registros de uma experiência em processo. Rio de Janeiro: Paz e Terra, 1977.

FREIRE, P. Vivendo e aprendendo: experiências do Idac em educação popular. São Paulo: Livraria Brasiliense editora s. a., 1980.

FREIRE, P., NOGUEIRA, A. Que Fazer: teoria e prática em educação popular. Petrópolis: Editora Vozes Ltda, 1991.

KONDER, L. Introdução ao fascismo. São Paulo: Expressão Popular, 2009.

PARIS, R. As origens do Fascismo. São Paulo: Editora Perspectiva S.A. 1976.

PILON, J. M., Desmarais, D. Les Enjeux Liés à la Pratique des Histoires de Vie au Carrefour de la Formation des Adultes, de la Recherche et de l'Intervention. In: DESMARAIS, D., PILON, J. M. (Coords.). Pratiques des Histoires de Vie - Au Carrefour de la Formation, de la Recherche et de l’Intervention. Paris: L’Harmattan, 1996, pp.11-24.

RAMOS, V. S. Os militares legalistas no putsh integralista pela imprensa carioca. In: I Simpósio Nacional de História Militar. 2016, Londrina. Anais [...] Londrina: Universidade Estadual de Londrina, 2016. Disponível em: http://www.uel.br/cch/his/ISNHM/AnaisPDF/viniciussramos.pdf. Acesso em 05 de jul. de 2020.

REICH, W. Psicologia de Massas do Fascismo. Tradução de Maria da Graça Monteiro Macedo. Lisboa: Publicações Dom Quixote, 1978.

SCARZANELLA, E. Fascisti in Sud América. Firenze: Le Lettere, 2005.

SCHWARTMAN, S., BOMENY, H. M. B., COSTA, V. M. R. Tempos de Capanema. Rio de Janeiro: Paz e Terra; São Paulo: EDUSP, 1984.

SCOCUGLIA, A. C. A pedagogia social de Paulo Freire como contraponto da Pedagogia Globalizada. In: MOURA, R.; NETO, J. C. de S. e SILVA, R. (org.). Pedagogia social. São Paulo: Expressão \& Arte Editora, 2009.

TORRES, R. M. Educação Popular: um encontro com Paulo Freire. São Paulo, Edições Loyola, 1987.

TRINDADE, H. Integralismo. Dicionário FGV CPDOC. s. d. Disponível em: http://www.fgv.br/Cpdoc/ Acervo/dicionarios/verbete-tematico/integralismo. Acesso em 21 de jul. de 2020.

TRINDADE, H. A tentação fascista no Brasil: imaginário de dirigentes e militantes integralistas. Porto Alegre, Editora da UFRGS, 2016.

TRINDADE, H. Integralismo (o fascismo brasileiro na década de 30). São Paulo: Difusão Européia do Livro, 1974.

VARGAS, G. Diário. São Paulo: Siciliano; Rio de Janeiro: Fundação Getúlio Vargas, 1995.

VARGAS, M. C. Vinte Anos do MST: Sempre é Tempo de Aprender. In: CONSTRUÇÃo coletiva: contribuições à educação de jovens e adultos. — Brasília: UNESCO, MEC, RAAAB, 2005. 362p. 